\title{
Insight photo therapy efektif meningkatkan keterampilan konseling guru Bimbingan dan Konseling di masa pandemi COVID-19
}

\author{
Agus Tri Susilo ${ }^{1 *}$, Ribut Purwaningrum²), Citra Tectona Suryawati3) \\ Universitas Sebelas Maret ${ }^{123}$ \\ *) Alamat korespondensi: Jl. Ir. Sutami No. 36 A, Surakarta, 57126, Indonesia; E-mail: ats@staff.uns.ac.id
}

\begin{abstract}
Article History:
Received: 01/02/2021;

Revised: $12 / 02 / 2021$;

Accepted: 17/02/2021;

Published: 28/02/2021.
\end{abstract}

How to cite:

Susilo, A.T., Purwaningrum, R., \& Suryawati, C.T.. (2021). Insight photo therapy efektif meningkatkan keterampilan konseling guru Bimbingan dan Konseling di masa pandemi COVID-19. Teraputik: Jurnal Bimbingan dan Konseling, 4(3), pp. 444-459. DOI: 10.26539/teraputik-43551
Abstrak: Studi didasarkan pada pentingnya keterampilan konseling guru Bimbingan dan Konseling di masa COVID-19. Tujuan penelitian adalah memaparkan hasil studi empirik mengenai keefektifan pelatihan insight photo therapy untuk meningkatkan keterampilan konseling Guru Bimbingan dan Konseling (BK) di masa pandemi COVID-19. Penelitian ini menggunakan metode eksperimen single-group pretest-posttest design melalui analisis paired samples $t$-test. Hasil pengujian hipotesis dari masing-masing aspek keterampilan konseling diketahui nilai sig. (2-tailed) sebesar 0,000 $<0,05$, artinya ada perbedaan mean pretest dan posttest keterampilan konseling melalui insight photo therapy. Hal ini bermakna bahwa pelatihan insight photo therapy efektif secara signifikan dalam meningkatkan keterampilan konseling Guru Bimbingan dan Konseling.

Keywords: Insight Photo Therapy, Counseling Skills

Abstract: The study is based on the importance of Guidance and Counseling teacher counseling skills in the COVID-19 era. The research objective is to present the results of an empirical study regarding the effectiveness of insight photo therapy training to improve counseling skills for Guidance and Counseling Teachers during the COVID-19 pandemic. This study used a singlegroup pretest-posttest design experiment method through analysis of paired samples t-test. The results of hypothesis testing from each aspect of counseling skills are known to be the sig value. ( 2 -tailed) of $0.000<0.05$, meaning that there is a difference in the mean pretest and posttest of counseling skills through insight photo therapy. This means that the insight photo therapy training is significantly effective in improving the counseling skills of the Guidance and Counseling Teacher.

Kata Kunci: Insight Photo Therapy, Keterampilan Konseling distributed under the article

Commons 4.0 Attribution

License, which permits

unrestricted use, distribution,

and reproduction in any medium,

provided the original work is

properly cited. @ 2021, Agus Tri

Susilo, Ribut Purwaningrum, \&

Citra Tectona Suryawati(s).

\section{Pendahuluan}

Guru Bimbingan dan Konseling (BK) idealnya memiliki keterampilan konseling yang baik, terutama dalam masa pandemic COVID-19. Hal ini dikarenakan, guru BK memiliki peranan yang sangat penting dalam membantu kestabilan emosi siswa. Sesuai dengan pendapat (Susanto, 2018), peranan guru BK adalah menyediakan ruang yang nyaman bagi kesulitan siswa, mendengarkan dan memberikan dukungan dengan memanfaatkan kekuatan diri individu untuk menjadi lebih baik.

Keterampilan konseling bagi guru BK ini akan sangat membantu dalam efisiensi dan efektivitas kinerja guru BK. Melihat fakta bahwa pandemi COVID-19 memiliki dampak sangat besar, terutama sangat mempengaruhi emosi masyarakat, khususnya siswa. COVID-19 telah mempengaruhi hampir setiap negara di dunia. Pada 9 Januari 2020, kematian pria kasus kematian pertama dilaporkan otoritas Cina akibat COVID-19. WHO menerbitkan sementara pedoman laboratorium untuk mendeteksi SARS-CoV-2 (WHO, 2020). Disampaikan bahwa per 7 Juni 2020, 
penyebaran COVID-19 terlihat secara global dengan sejumlah kasus besar dan kematian yang dikonfirmasi. WHO menetapkan enam wilayah untuk mendistribusikan penyakit COVID-19.

Secara spesifik, dampak COVID-19 telah mempengaruhi semua jenjang sistem pendidikan, mulai dari pra-sekolah hingga pendidikan tinggi. Berbagai negara telah memperkenalkan berbagai kebijakan, mulai dari penutupan total di Jerman dan Italia (Meier et al., 2020) hingga penutupan yang ditargetkan di Inggris untuk semua, kecuali anak-anak pekerja di industri utama (Prabhakar, 2020). Masih dalam literatur yang sama, lebih dari seratus negara telah memberlakukan penutupan fasilitas pendidikan secara nasional. UNESCO memperkirakan hampir sembilan ratus juta peserta didik telah terpengaruh oleh penutupan lembaga pendidikan. Sementara tujuan dari penutupan ini untuk mencegah penyebaran virus di dalam institusi dan mencegah penyebaran ke individu yang rentan, penutupan ini memiliki implikasi sosial ekonomi yang luas.

Dampak penutupan sekolah dalam jangka panjang masih belum terlihat. Namun sebuah studi oleh (Chen, et al., 2011) dari satu minggu penutupan sekolah di Taiwan selama wabah H1N1 2009 menemukan bahwa 27\% keluarga tidak dapat bekerja, dengan 18\% kehilangan pendapatan sebagai akibat langsungnya. Sebuah studi oleh Brookings Institution (Brooking.Edu, 2020), pemodelan penutupan di kota-kota besar AS dan nasional, menyarankan bahwa akan ada biaya rata-rata \$ 142 per siswa per minggu. Perkiraan di Inggris menunjukkan bahwa penutupan yang berlarut-larut dapat menelan biaya 3\% dari PDB Inggris (Keogh-Brown, et al. 2020). Namun, WrenLewis (Nicola et al., 2020) berpendapat bahwa dampak ini akan berumur pendek karena penyebabnya diketahui dan didefinisikan, oleh karena itu akan memiliki titik akhir yang jelas, tidak seperti resesi ekonomi normal. Kondisi yang sama terjadi di Indonesia, dampak COVID-19 menghadirkan potret evaluasi pembelajaran melalui sistem jarak jauh atau "learning from home", sebuah kajian di 4 provinsi awal di Indonesia. Seperti di negara lain, pemerintah mengeluarkan kebijakan belajar dari rumah disaat negara dalam keadaan darurat COVID-19 (Putra, et al., 2020)

COVID-19 juga mempengaruhi sektor tersier. Selain dampak pada pendidikan sarjana (Alsafi, et al., 2020), dampak paling signifikan adalah pada komunitas penelitian pascasarjana yang meneliti tentang topik terkait non-COVID, banyak ditangguhkan. Di Inggris Raya, badan pendanaan nasional memungkinkan staf yang terlatih secara klinis untuk melakukan penugasan akademis untuk kembali ke garis depan (DHSC, 2020). Di Amerika Serikat, tindakan serupa telah diambil oleh National Institute for Health untuk menutup semua penelitian non-kritis agar membebaskan staf dan sumber daya untuk penelitian 'misi-kritis' (Nayak et al., 2020). Selain itu, beberapa institusi telah menunda penelitian di bidang humaniora dan sosial misalnya Universitas Harvard menutup semua laboratorium di Fakultas Seni dan Sains (Nicola et al., 2020). Relevan dengan kondisi di Indonesia, (Faqir, 2020) melaporkan bahwa lebih dari 646.200 sekolah dan universitas ditutup dan siswa diwajibkan untuk belajar jarak jauh. Selain itu, berbagai analisis terkait penutupan nasional akhirnya memiliki dampak besar pada pendidikan terutama kesulitan siswa yang berada di daerah terpencil dengan kondisi sosial ekonomi berbeda. Mayoritas masyarakat merasakan dan memprihatinkan hal tersebut karena hingga saat ini wabah belum berakhir.

Dampak global akibat COVID-19 sungguh nyata, termasuk kondisi penutupan sekolah di berbagai wilayah Indonesia yang ditunjukkan pada peta interaktif penutupan sekolah sebagai tanggapan terhadap pandemic (WHO, 2020). Pada peta tersebut, dapat dideskripsikan bahwa Indonesia masuk pada kriteria wajib menutup sekolah, kecuali wilayah-wilayah tertentu saja yang sudah benar-benar mampu mengendalikan kasus COVID-19. Hal ini menyebabkan 94\% wilayah di Indonesia memberlakukan pembelajaran jarak jauh untuk memutuskan mata rantai penyebaran COVID-19 (Usman, 2020). Bentuk pembelajaran pada masa COVID-19 melalui pembelajaran online. Menurut (Singh \& Thurman, 2019), pembelajaran online adalah pembelajaran yang menggunakan internet untuk memunculkan interaksi pembelajaran.

Selama epidemi COVID-19, tingkat kecemasan dan depresi siswa meningkat secara signifikan, yang juga terkait dengan banyak faktor. Oleh karena itu, sangat penting untuk melakukan intervensi psikologis berorientasi krisis yang diperlukan pada siswa (Cao et al., 2020). Menurut Nova (Widowati, 2019), terdapat lima fase krisis, antara lain: (1) pre-crisis, benih krisis mulai muncul, tetapi masih ada asa; (2) warning, tahap krusial harus dicari solusinya sebelum semakin buruk; (3) acute crisis, sudah menimbulkan dampak buruk; (4) clean up, sudah mampu berdamai dengan masalahnya; (5) post-crisis, sudah kembali bersemangat. 
Fenomena tingkat kecemasan dan depresi siswa tersebut di atas memunculkan kebutuhan yang sangat besar bagi guru BK untuk bergerak membantu. Bantuan ini tidak serta merta diberikan tanpa landasan ilmu. Dibutuhkan suatu cara yang efektif efisien mengingat tingkat stres siswa yang sangat tinggi. Gladding (Fauziah \& Hartanto, 2020) mengemukakan bahwa penanganan permasalahan krisis mengenai apa yang harus dilakukan konselor dan kapan penanganan diberikan tergantung kepada hasil asesmen dan penelitian konselor itu sendiri. Menurut (R. L. \& M. H. M. Gibson, 2011) penggunaan konseling krisis dan Critical Incident Stresse Debriefing (CISD) dapat dijadikan alternatif penanganan masalah krisis psikologis. CISD merupakan pendekatan kelompok yang berorintasi tujuh tahap untuk membantu klien menghadapi perspektif, beliefs dan perasaan dalam suatu situasi terkontrol dengan melibatkan dua konselor.

Konseling krisis adalah konseling yang memanfaatkan berbagai pendekatan directive dan berorientasi tindakan, untuk membantu klien dalam menggali potensi menghadapi krisis secara eksteral (Rahayu, 2017). Dikutip dari (Al-Sulaiman et al., 2018) konseling krisis didesain untuk menolong klien mengidentifikasi dan mengimplementasikan bermacam jenis konseling krisis serta mengevaluasi dan mengindentifikasi reaksi umum dari krisis dan gejalanya. Selain itu, juga memanajemen stress dan menyadari dampaknya. Penggunaan bermacam pendekatan directive dan berfokus ke tindakan (Rahayu, 2017).

(Romli, 2017) treatment yang dapat dilakukan untuk mereduksi atau mengentaskan permasalahan stres dan krisis pada remaja dilakukan oleh konselor dengan beberapa strategi: terapi bermain, smile child center, terapi kreatif, terapi emosi dan outbond. Di sini terdapat peluang bahwa terapi emosi dan kognitif dengan menggunakan insight photo therapy. Insight photo therapy adalah pendekatan baru dalam dunia Bimbingan Konseling menggunakan media gambar yang bertujuan untuk menstimulasi memori, emosi dan pengalaman masa lalu sehingga dapat menghasilkan sudut pandang baru (insight) dan pada akhirnya menjadi solusi atas permasalahan yang dialami konseli (Yudha, 2019). Insight photo therapy adalah praktik terapi yang menggunakan foto pribadi orang, album keluarga, dan atau gambar yang diambil oleh orang lain (perasaan, pikiran, ingatan, dan keyakinan yang ditimbulkan oleh foto-foto ini) sebagai katalis untuk memperdalam wawasan dan meningkatkan komunikasi selama sesi terapi atau konseling mereka dengan cara yang tidak mungkin dilakukan dengan kata-kata saja.

Insight photo therapy digunakan untuk meningkatkan pengetahuan diri, kesadaran, kesejahteraan diri, meningkatkan hubungan mereka dengan keluarga dan orang lain, mengaktifkan perubahan sosial yang positif, mengurangi pengucilan sosial, membantu rehabilitasi, memperkuat komunitas, memperdalam hubungan antar budaya, mengurangi konflik, memperhatikan masalah ketidakadilan sosial, mempertajam keterampilan literasi visual, meningkatkan pendidikan, dan menghasilkan jenis lain dari penyelesaian pribadi/emosional, sosial, akademik dan karier berbasis foto. Setiap foto yang diambil atau disimpan seseorang merupakan jenis potret diri, sejenis cermin dengan ingatan yang merefleksikan kembali saat-saat itu dan orang-orang yang cukup spesial untuk dibekukan dalam waktu selamanya. Secara kolektif, Weiser (Tourigny \& Naydenova, 2020) foto-foto ini membuat kisah nyata dari kehidupan orang itu terlihat, berfungsi sebagai jejak kaki visual yang menandai di mana mereka berada (secara emosional, juga secara fisik) dan mungkin juga memberi sinyal ke mana mereka akan pergi. Bahkan reaksi orang terhadap kartu pos, gambar majalah, gambar online, atau foto yang diambil oleh orang lain dapat memberikan petunjuk yang menerangi kehidupan batin mereka sendiri dan rahasianya.

Kelebihan dari gambar atau foto dalam Insight photo therapy menurut (Yudha, 2019) di antaranya: (1) Gambar mampu menjelaskan 1000 makna kata-kata; (2) Gambar yang sama memiliki significant effect yang berbeda antar individu; (3) Gambar mampu membangkitkan memori yang tertanam di ambang/bawah sadar; (4) Gambar memiliki daya jangkar (anchor) yang lebih kuat dibandingkan dengan kata-kata; (5) Konseling menggunakan gambar memiliki efek jangka panjang (multi-sensory) dibandingkan hanya dengan kata-kata saja.

Hal-hal yang perlu diperhatikan dan akan ditemukan pada proses Insight photo therapy adalah sebagai berikut: (1) Berikan jeda dan temukan, meluangkan waktu sejenak untuk melihat kehidupan dari perspektif yang berbeda. Memungkinkan kita melihat gambar dengan lebih detail, otentik, dan tidak sekedar menghakimi diri \& orang lain; (2) Pandangan yang diperluas, dalam situasi apa pun, ada banyak titik atau tampilan. Tantangan sebenarnya adalah saat berhasil dalam melihat sudut pandang selain dari yang biasanya, dan untuk mengamati hal-hal dari sudut pandang 
baru; (3) Dialog konstruktif, menyebarkan seluruh kesatuan gambar dan teks (jika ada), menyentuh masalah lebih kompleks, memungkinkan kita untuk berkomunikasi internal, dan mengubah dialog kita menjadi sesuatu yang efektif; (4) Fokus untuk langkah selanjutnya, merumuskan wawasan baru dan menentukan tindakan untuk masa depan.

Selanjutnya, tahapan atau prosedur Insight photo therapy cukup sistematis dan operasional, yaitu: (1) Framing, memilih masalah dari kehidupan sehari-hari konseli, masalah yang dikhawatirkan; mungkin sesuatu yang ingin dilihat secara mendalam (hubungan pribadi, karier, keluarga, teman, dan seterusnya) bingkai masalah konseli sebagai pertanyaan; (2) Choosing, mengajak konseli untuk memilih kartu secara intuitif, menghadap ke atas atau ke bawah; (3) Expanding, mendorong konseli untuk mengamati setiap kartu dengan cermat, perhatikan pikiran dan perasaan yang datang; (4) Focusing, menanyakan pada konseli, "sudut pandang apa yang paling signifikan atau bermakna dari pengamatan ini?". Konselor mengarahkan sudut pandang dari gambar yang diamati dengan mengkorelasikan permasalahan yang sedang dikhawatirkan konseli; (5) Doing, pertanyaan panduan konselor pada konseli adalah "Bagaimana Saudara bisa menerapkan sudut pandang tersebut ke dalam kehidupan nyata nanti"? artinya bahwa mengarahkan konseli mampu merumuskan langkah-langkah konkrit yang segera dilakukan setelah sesi konseling ini (Yudha, 2019).

Berpedoman dengan konsep, kelebihan, hal-hal yang akan ditemukan dan tahapan sistematis dari Insight photo therapy, memberikan harapan, tantangan dan peluang bagi Guru BK atau Konselor agar mampu upgrading keterampilan konselingnya khususnya di masa darurat pandemi COVID-19 seperti ini. Hasil studi eksplorasi yang dilakukan oleh peneliti beberapa waktu lalu terhadap sembilan puluh satu Guru BK di Kabupaten Karanganyar dan Wonogiri dengan rincian $77(84,6 \%)$ Guru BK Sekolah Menengah Atas atau Sekolah Menengah Kejuruan sederajat dan 14 (15,4\%) Guru BK Sekolah Menengah Pertama sederajat menunjukkan bahwa 53,8\% Para Guru BK melaksanakan kegiatan layanan konseling melalui dalam jaringan (daring), 44\% memilih untuk blended (kadang tatap muka, kadang daring) dan sisanya tatap muka atau luar jaringan (luring). Selama masa Pembelajaran Jarak Jauh masa pandemi, 35,2\% Guru BK merencanakan secara periodik kegiatan layanan konseling individual maupun kelompok, 59,3\% Guru BK tidak merencanakan itu dan sifatnya sangat insidental.

Analisis lebih lanjut tentang kebutuhan penanganan masalah selama PJJ menunjukkan bahwa permasalahan bidang akademik menjadi prioritas utama sebesar $75,8 \%$, hampir sama dengan bidang pribadi $74,7 \%$ selanjutnya bidang karier $36,3 \%$ dan bidang sosial $29,7 \%$. Saat diidentifikasi lebih spesifik, beberapa masalah yang muncul dari siswa selama PJJ di masa pandemi COVID-19 ini di antaranya adalah kebosanan di rumah, banyak tugas sekolah, kejenuhan belajar, motivasi belajar rendah, penyelesaian penelusuran bakat, minat dan arah karier, kontrol orang tua yang kurang di rumah, siswa kurang aktif saat konseling, manajemen waktu, kendala sinyal, dukungan dan pendampingan orang tua, terkendala oleh alat (HP/ Laptop), jaringan, kouta/pulsa, dan masih banyak lagi.

Kajian empiris peneliti juga menggali informasi tentang kendala saat pelayanan konseling secara daring, diketahui hasilnya bahwa 59,3\% dan 31,9\% Guru BK mengalami hambatan ketidakoptimalan penerapan keterampilan komunikasi konseling serta pendekatan konseling apa yang akan digunakan. Kemudian, pada saat diberikan pertanyaan lebih jauh tentang penerapan konseling online berorientasi krisis dan insight photo therapy selama pandemi COVID-19, hasilnya 92\% Guru BK menyatakan belum pernah menerapkan atau mempraktikkan layanan konseling tersebut kepada siswa.

Berdasarkan kajian teoritis, analisis literatur, hasil-hasil penelitian yang relevan, dan kajian empiris yang telah dilakukan peneliti, tampaknya menjadi suatu tantangan dan peluang untuk melakukan studi eksperimentasi dengan konsep pelatihan insight photo therapy untuk meningkatkan keterampilan konseling Guru BK di masa pandemi COVID-19 pada Musyawarah Guru Bimbingan Konseling (MGBK) Kabupaten Karanganyar dan Wonogiri.

Oleh karena itu, rumusan masalah dalam penelitian adalah "Bagaimana efektivitas pelatihan Insight Photo Therapy untuk meningkatkan keterampilan konseling Guru BK di masa pandemi COVID-19?". Tujuan penelitian adalah memaparkan hasil uji empirik mengenai keefektifan pelatihan insight photo therapy untuk meningkatkan keterampilan konseling Guru BK di masa pandemi COVID-19. 
Manfaat penelitian diharapkan dapat dirasakan bagi guru BK, siswa, sekolah, dan pengembangan ilmu pengetahuan Bimbingan Konseling. Bagi guru BK, penelitian diharapkan dapat membantu agar guru BK senantiasa upgraiding wawasan, sikap dan keterampilan konseling di masa pandemi COVID-19. Bagi siswa, peningkatan skill guru BK diharapkan dapat membantu meringankan stres di masa pandemi. Bagi sekolah, siswa yang terbantukan dengan adanya guru BK yang memiliki skill baik akan membuat prestasi belajar siswa lebih baik dan tentu meningkatkan nama baik sekolah juga. Bagi pengembangan ilmu pengetahuan Bimbingan Konseling, penelitian diharapkan memberikan sumbangsih terutama bagi Guru BK untuk dapat menjadikan insight photo therapy sebagai teknik alternatif dalam melakukan konseling.

Hipotesis dalam penelitian dirumuskan, yaitu Hipotesis kerja $\left(\mathrm{H}_{\mathrm{a}}\right)$ berbunyi ada pengaruh pelatihan insight photo therapy untuk meningkatkan keterampilan konseling Guru BK. Hipotesis nol $\left(\mathrm{H}_{0}\right)$ berbunyi tidak ada pengaruh pelatihan insight photo therapy untuk meningkatkan keterampilan konseling Guru BK.

\section{Metode}

Metode penelitian yang dipilih adalah eksperimen kelompok tunggal (Sugiyono, 2018). Desain penelitian eksperimen menggunakan single-group pretest-posttest design. Desain ini dipilih karena sangat fleksibel disesuaikan dengan kebutuhan sampel penelitian. Pada pelaksanaan eksperimen dimulai dengan melakukan pretest atau pengukuran kondisi awal (data awal), dilanjutkan dengan pemberian perlakuan yaitu pelatihan insight photo therapy, dan diakhiri dengan posttest atau pengukuran kondisi akhir (data akhir/ setelah perlakuan).

Penelitian diawali dengan studi literatur, penyusunan rencana, penyusunan instrumen, pengujian instrumen, revisi instrumen, penyusunan materi, pengumpulan data, pelaksanaan, pengumpulan data, analisis data, penyusunan laporan, hingga penyusunan luaran artikel ilmiah.

Penelitian dilakukan selama kurang lebih enam bulan, dari bulan September 2020 hingga bulan Januari 2021. Kegiatan penelitian dan pelatihan dilaksanakan secara virtual melalui zoom cloud meeting selama empat kali pertemuan, mulai tanggal 3-6 November 2020. Populasi penelitian adalah Guru BK Sekolah Menengah Kejuruan (SMK) di Kabupaten Karanganyar dan Sekolah Menengah Atas (SMA) di Kabupaten Wonogiri yang tergabung pada MGBK serta mahasiswa Pendidikan Profesi Guru (PPG) dalam jabatan BK di Universitas Sebelas Maret yang berjumlah 218 orang. Metode sampling dalam penelitian menggunakan teknik purposive sampling, yaitu peserta kegiatan pelatihan online dalam penelitian ini. Jumlah sampel penelitian adalah seratus peserta yang terdiri dari empat puluh tiga Guru BK SMP-SMA Kab. Karanganyar, dua puluh sembilan Guru BK SMP-SMA Kab. Wonogiri, dan dua puluh delapan Guru BK Mahasiswa PPG BK UNS tahun 2020.

Instrumen yang digunakan adalah angket yang mengacu pada evaluasi proses dan hasil dari kegiatan pelatihan insight photo therapy yang didistribusikan melalui google form. Pendekatan untuk memastikan validitas instrumen adalah pendekatan konstruk. Pendekatan untuk memastikan reliabilitas instrumen adalah konsistensi internal.

Kegiatan penelitian ini berbasis experiential dan vicarious learning dengan menggunakan pendekatan konstruktivistik dan humanistik, yaitu melatih Guru BK SMP \& SMA dalam mengembangkan keterampilan pelaksanaan konseling melalui insight photo therapy. Pelaksanaannya dilakukan dengan tahapan kegiatan sebagai berikut.

1. Pra kegiatan. Pengembangan panduan pelaksanaan pelatihan yang akan digunakan sebagai pedoman pelaksanaan pelatihan. Pengembangan panduan dilakukan dengan langkah-langkah penelitian \& pengembangan termasuk proses validasi yang akan dilakukan Borg \& Gall (Surur et al., 2020) dengan langkah-langkah sebagai berikut:

a. Tahap pertama, melakukan pengkajian terhadap konsep insight photo therapy secara detail. Pengkajian ini dimaksudkan untuk menemukan esensi konsep dan teori konseling secara spesifik serta aspek-aspek atau komponen-komponen yang tercakup di dalam konsep tersebut.

b. Tahap kedua, melakukan kajian terhadap esensi konsep pelaksanaan insight photo therapy. Berdasarkan kajian terhadap konsep tersebut dihasilkan hal-hal penting antara 
lain bahwa unsur-unsur pelaksanaan konseling meliputi tahapan-tahapan yaitu: 1) tahap awal konseling; 2) tahap kerja; dan 3) tahap akhir konseling. Pada proses pelaksanaan tahapan konseling bertujuan agar peserta didik mampu: 1) berpikir realistis bahwa peristiwa krisis psikologis menjadi bagian dari kehidupan; 2) memperoleh pemahaman situasi yang menimbulkan krisis; 3) memahami dan menerima perasaan krisis; 4) belajar keterampilan baru (Muro and Kottman).

c. Tahap ketiga, atas dasar hasil kajian konsep dan teori insight photo therapy, kemudian dikembangkan draf awal panduan untuk mereduksi krisis psikologis peserta didik.

d. Tahap keempat, melakukan pengujian draf awal panduan. Pengujian pertama adalah uji ahli, dilakukan oleh ahli di bidang bimbingan konseling yang mendalami konseling krisis dengan insight photo therapy.

e. Tahap kelima, melakukan revisi atau perbaikan panduan masukan dari para penilai yaitu para ahli.

f. Setelah dilakukan revisi atau perbaikan, tahap keenam adalah melaksanakan panduan ke lapangan sebagai ujicoba (dicobakan kepada beberapa guru).

g. Tahap ketujuh, melakukan revisi ulang atas dasar masukan dari hasil uji coba pada kelompok sasaran guru.

h. Tahap kedelapan, menggunakan panduan untuk kegiatan pelatihan.

2. Tahap coaching, yaitu melatih anggota dan co-trainer yang akan dimintai bantuan dalam melaksanakan pelatihan. Tujuannya agar para anggota terdapat kesamaan persepsi dan ada kesesuaian langkah-langkah yang ditetapkan dalam panduan sehingga pelaksanaannya benar-benar sesuai dengan ketentuan.

3. Tahap kegiatan. Pelaksanaan pelatihan kepada guru BK SMP \& SMA di Kabupaten Karanganyar \& Wonogiri serta Mahasiswa PPG BK UNS. Guru BK SMP, SMA dan mahasiswa PPG BK UNS adalah sampel guru di Kabupaten Karanganyar dan Wonogiri yaitu empat puluh tiga orang Guru BK SMP-SMA Kabupaten Karanganyar; dua puluh sembilan orang Guru BK SMP-SMA Kabupaten Wonogiri dan 28 orang Guru BK sebagai Mahasiswa PPG BK dalam jabatan UNS tahun 2020. Sampel tersebut diwadahi dalam kelompok MGBK. Pemilihan sampel didasarkan pada hasil analisis bahwa Guru BK merasa kurang memiliki kompetensi dalam konseling. Kegiatan pelatihan dilakukan empat kali pertemuan (di luar pre-test postptest) secara daring dan yang setara dengan tiga puluh dua Jam Pelatihan (JP). Rincian kegiatan yaitu: hari pertama webinar, hari kedua pendampingan pelatihan, hari ketiga praktik mandiri dan hari keempat penugasan serta pelaopran. Saat kegiatan hari pertama, peneliti mengirimkan link presensi sekaligus instrumen pengukuran kondisi (data awal tentang keterampilan insight photo therapy/ pretest).

4. Pasca kegiatan. Setelah pelatihan berakhir, kegiatan berikutnya adalah melakukan evaluasi. Wujud evaluasinya adalah: (a) mengukur perubahan yang terjadi pada diri guru yang telah mengikuti pelatihan dengan alat ukur keterampilan pelaksanaan insight photo therapy (posttest), (b) mengevaluasi proses pelaksanaan kegiatan, termasuk menyusun laporan kegiatan.

Selanjutnya, data pretest \& posttest dilakukan analisis dengan menggunakan uji beda (paired sample t-test) untuk menganalisis perubahan kondisi awal dan akhir yang meliputi: (1) penguasaan konsep tentang insight photo therapy; (2) penguasaan tahapan/ prosedur insight photo therapy; (3) Keterampilan mempraktikkan insight photo therapy; dan (4) keberhasilan membantu menyelesaikan gangguan psikologis pada siswa melalui insight photo therapy.

Peralatan dan bahan penunjang penelitian, antara lain: manual book, form instrumen evaluasi, template rencana pelaksanaan layanan, akses internet memadai, photo therapy. Rencana analisis dalam penelitian ini menggunakan statistik deskriptif \& inferensial (paired sample t-test) (Sugiyono, 2018).

Lingkup dan atau keterbatasan metode penelitian ini adalah metode penelitian ini menggunakan single-group pretest-posttest design. Desain ini dipilih karena tidak memungkinkan untuk dilakukan kegiatan pelatihan dengan kelompok kontrol, terutama di masa pandemi ini. Sebagai gantinya, kelebihan penelitian ini adalah berjumlah sampel seratus orang. Dalam penelitian eksperimen menurut (Creswell \& Creswell, 2017), idealnya minimal berjumlah lima belas 
orang. Keterbatasan kedua pada metode penelitian ini adalah pelaksanaan pelatihan yang dilaksanakan secara virtual melaui zoom cloud meeting. Hal ini dilakukan mengingat adanya Pembatasan Sosial Berskala Besar (PSBB), anjuran pemerintah untuk mengurangi pertemuan tatap muka dalam jumlah besar secara langsung. Keterbatasan ketiga dalam metode penelitian ini adalah tindakan pada pertemuan pertama, kedua, ketiga, dan keempat masing-masing tidak bisa dilakukan dengan jeda idealnya satu minggu. Sekali lagi, hal ini dikarenakan kegiatan dilakukan dalam bentuk pelatihan virtual yang merupakan dampak dari adanya PSBB. Namun, di luar keterbatasan tersebut, segala upaya telah dilakukan agar prosedur penelitian yang berlangsung tetap berjalan secara profesional.

\section{Hasil dan Diskusi}

Uraian kegiatan secara ringkas yaitu: (1) Webinar selama delapan Jam Pembelajaran (JP) dengan empat narasumber ahli di bidang konseling (Dr. Eka Sakti Yudha, M.Pd, Mulawarman, Ph.D, Dr. Ribut Purwaningrum, M.Pd, dan Agus Tri Susilo, S.Pd., M.Pd.); (2) pendampingan dan praktik latihan terbimbing insight photo therapy oleh tim peneliti selama delapan Jam Pelajaran (JP); (3) Pelaksanaan penerapan atau latihan praktik mandiri oleh Guru BK pada siswa selama delapan JP; (4) Review dan pengumpulan laporan hasil kerja praktik mandiri selama delapan JP. Data pretest didapatkan dari instrumen yang telah diisi oleh peserta di pertemuan pertama dan data posttest didapatkan dari instrumen evaluasi proses maupun hasil di pertemuan terakhir. Data pretest \& posttest dianalisis secara statistik menggunakan uji beda (paired sample $t$-test). Data hasil pretest dapat disajikan pada Tabel 1 berikut.

Tabel 1. Hasil pretest keterampilan konseling melalui insight photo therapy

\begin{tabular}{clcc}
\hline No. & \multicolumn{1}{c}{ Aspek } & Mean & N (Jumlah Subjek) \\
\hline 1 & Penguasaan konsep insight photo therapy & 4,44 & 100 \\
\hline 2 & Penguasaan prosedur insight photo therapy & 4,49 & 100 \\
\hline 3 & Penguasaan keterampilan praktik mandiri & 6,93 & 100 \\
\hline 4 & Keberhasilan menyelesaikan masalah siswa & 7,05 & 100 \\
\hline
\end{tabular}

Keterangan: mean dihitung dari jumlah nilai dibagi jumlah subjek dalam skala 1-10.

Terdapat 4 (empat) aspek yang diukur pada kondisi awal keterampilan konseling melalui insight photo therapy, yaitu: penguasaan konsep insight photo therapy, penguasaan prosedur insight photo therapy, penguasaan keterampilan praktik mandiri, dan keberhasilan menyelesaikan masalah siswa. Pada awal sesi pelatihan, para guru BK menyadari dan merasa bahwa insight photo therapy adalah salah satu pendekatan konseling yang relatif baru bagi mereka dan $92 \%$ dari subjek belum pernah melakukan kegiatan layanan tersebut. Hal ini berimplikasi pada hasil skor mean berturut-turut: 4,44; 4,49; 6,93; dan 7,05. 
Hasil pre-test tersebut juga divisualisasikan lebih jelas pada diagram batang berikut. Berikut ini Gambar 1. Diagram kondisi awal keterampilan konseling melalui insight photo therapy.

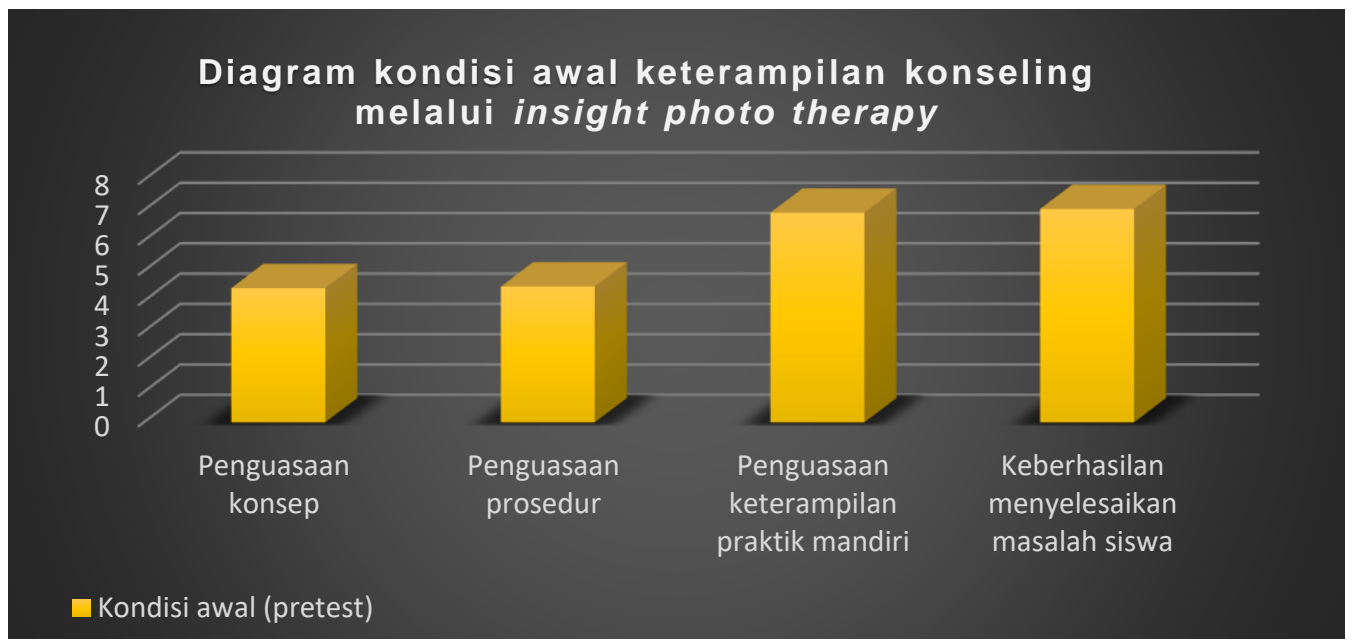

Gambar 1. Diagram kondisi awal keterampilan konseling melalui insight photo therapy

Berdasarkan Gambar 1 di atas, tampak bahwa kondisi awal keterampilan konseling melalui insight photo therapy peserta berada pada tingkat paling rendah ke tinggi dimulai dari penguasaan konsep, penguasaan prosedur, penguasaan keterampilan praktik mandiri, dan keberhasilan menyelesaikan masalah siswa. Selanjutnya, hasil pre-test dikomparasikan dengan hasil posttest pasca perlakuan pelatihan insight photo therapy pada tabel berikut ini.

Tabel 2. Hasil posttest keterampilan konseling melalui insight photo therapy

\begin{tabular}{clcc}
\hline No. & \multicolumn{1}{c}{ Aspek } & Mean & N (Jumlah Subjek) \\
\hline 1 & Penguasaan konsep insight photo therapy & 7,72 & 100 \\
\hline 2 & Penguasaan prosedur insight photo therapy & 7,79 & 100 \\
\hline 3 & Penguasaan keterampilan praktik mandiri & 7,72 & 100 \\
\hline 4 & Keberhasilan membantu menyelesaikan masalah siswa & 7,70 & 100 \\
\hline
\end{tabular}

Keterangan: mean di hitung dari jumlah nilai dibagi jumlah subjek dalam skala 1-10.

Sumber: Diolah dari data penelitian, 2020

Berdasarkan hasil dari posttest, skor mean keterampilan konseling melalui insight photo therapy mengalami kenaikan di semua aspek. Mulai dari penguasaan konsep insight photo therapy, penguasaan prosedur insight photo therapy, penguasaan keterampilan praktik mandiri dan keberhasilan membantu menyelesaikan masalah siswa. Berturut-turut hasilnya yaitu 7,72; 7,$79 ; 7,72$; dan 7,70 . Hal ini juga dipertegas dengan rencana tindak lanjut yang dirumuskan oleh subjek sebagai berikut.

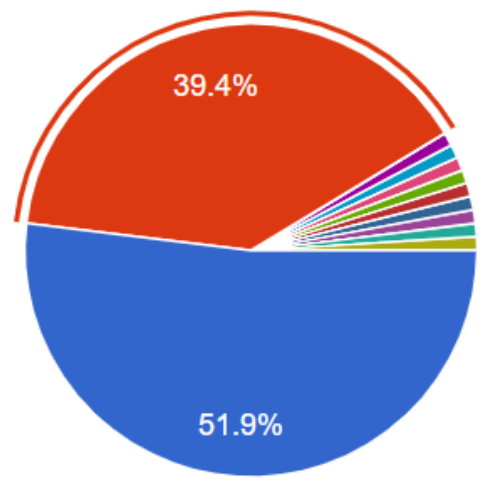

Saya segera mencoba

Saya masih ingin belajar lagi

Saya pikir-pikir kembali

Saya tidak akan mencoba

saya ingin segera mencoba dan masi...

Menyesuaikan masalah client

saya telah mencoba sekali kepada sis...

saya akan pelajari lagi rekaman mater...

Gambar 2. Rencana tindak lanjut pasca pelatihan insight photo therapy 
Berdasarkan diagram lingkaran pada Gambar 2 dapat dirumuskan bahwa 51,9\% guru BK ingin segera mencoba menerapkan insight photo therapy di sekolah masing-masing. 39,4\% masih ingin belajar lagi dan sisanya masih ingin berpikir-pikir kembali untuk mencoba dan menerapkannya. Makna dari hal tersebut adalah ada harapan dan antusiasme yang baik dari para guru BK dalam upaya meningkatkan keterampilan konselingnya di masa pandemi ini, salah satunya melalui insight photo therapy. Hasil skor mean posttest secara visual bisa diperjelas dalam Gambar 3 berikut.

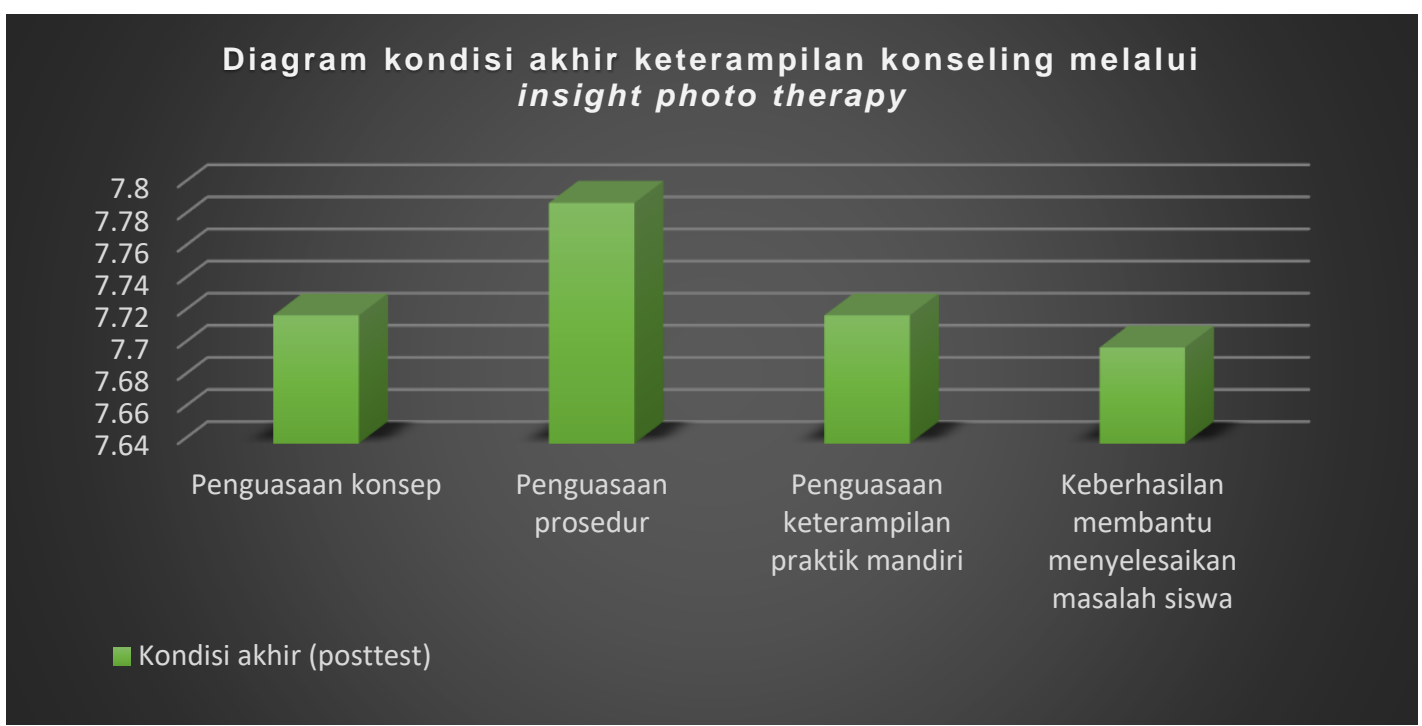

Gambar 3. Diagram kondisi akhir (posttest) keterampilan konseling melalui insight photo therapy

Selanjutnya dilakukan pengujian hipotesis, yaitu "Adakah perbedaan penguasaan keterampilan konseling melalui insight photo therapy sebelum dan sesudah diberikan perlakuan", dengan menggunakan pedoman pengujian paired sample t-test berdasarkan nilai signifikansi "Jika nilai signifikansi (sig. 2-tailed) < 0,05 maka $\mathrm{H}_{0}$ (hipotesis nol) ditolak dan $\mathrm{H}_{a}$ (Hipotesis alternatif/ tindakan) diterima, dan begitu sebaliknya" (Santoso, 2014).

Hasil pengujian hipotesis ditunjukkan pada tabel dan grafik. Berikut ini adalah Tabel 3. Perbandingan hasil skor mean pretest dan posttest.

Tabel 3. Perbandingan hasil skor mean pretest dan posttest

\begin{tabular}{clcccc} 
No. & \multicolumn{1}{c}{ Aspek } & $\begin{array}{c}\text { Mean } \\
\text { pretest }\end{array}$ & $\begin{array}{c}\text { Mean } \\
\text { posttest }\end{array}$ & $\begin{array}{c}\text { Gain } \\
\text { Score }\end{array}$ & $\begin{array}{c}\text { N } \\
\text { (Jumlah } \\
\text { Subjek) }\end{array}$ \\
\hline 1 & Penguasaan konsep insight photo therapy & 4,44 & 7,72 & 3,28 & 100 \\
\hline 2 & Penguasaan prosedur insight photo therapy & 4,49 & 7,79 & 3,30 & 100 \\
\hline 3 & $\begin{array}{l}\text { Penguasaan keterampilan praktik mandiri } \\
\text { Keberhasilan membantu menyelesaikan }\end{array}$ & 6,93 & 7,72 & 0,79 & 100 \\
\hline & 7,05 & 7,70 & 0,65 & 100 \\
\hline
\end{tabular}


Berikut ini adalah Gambar 4. Perbandingan kondisi awal (pretest) dan kondisi akhir (posttest) keterampilan konseling.

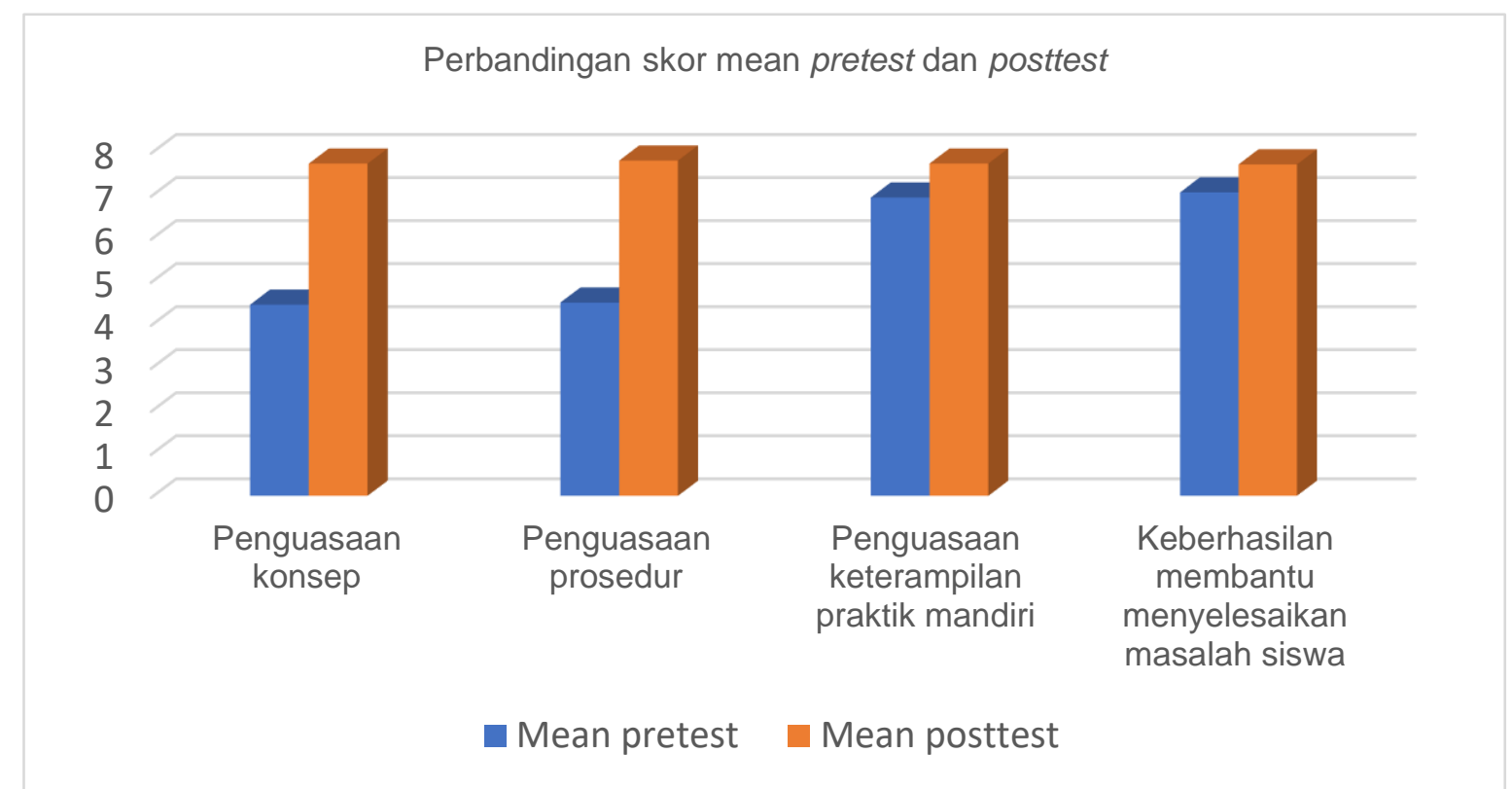

Gambar 4. Perbandingan kondisi awal (pretest) dan kondisi akhir (posttest) keterampilan konseling

Berdasarkan sajian pada tabel dan diagram batang tersebut, dapat kita deskripsikan bahwa terdapat kenaikan skor mean dari masing-masing aspek berturut-turut sebesar 3,28; 3,3; 0,78 dan 0,65 . Setelah mampu mendeskripsikan perubahan skor masing-masing aspek, selanjutnya akan dihitung analisis uji beda kondisi sebelum perlakuan yaitu pelatihan insight photo therapy dengan sesudah perlakuan dengan menggunakan uji paired sample t-test. Hasil pengujian masing-masing aspek, antara lain:

\section{Penguasaaan konsep insight photo therapy}

Pada output ini diperlihatkan ringkasan hasil statistik deskriptif dari kedua sampel yang diteliti yaitu nilai pretest dan posttest. Nilai pretest diperoleh rata-rata penguasaan konsep insight photo therapy sebesar 4,44 . Sedangkan untuk nilai posttest diperoleh nilai rata-rata penguasaan konsep insight photo therapy sebesar 7,72. Jumlah responden atau subjek penelitian adalah sebanyak 100 orang. Nilai standar std. Deviation (standar deviasi) pada pretest sebesar 2,100 dan posttest 1,006. Terakhir adalah nilai std. Error mean untuk pretest sebesar 0,210 dan untuk posttest sebesar 0,101.

Karena nilai rata-rata penguasaan konsep insight photo therapy pada pretest 4,44 $<$ posttest 7,72, maka artinya secara deskriptif ada perbedaan rata-rata penguasaan konsep insight photo therapy antara pretest \& posttest. Untuk membuktikan apakah perbedaan signifikan, perlu ditafsirkan pada hasil uji paired sample $t$ test. Diketahui nilai koefisien korelasi sebesar 0,322 dengan nilai signifikansi sebesar 0,001. Karena nilai sig. 0,001 < probabilitas 0,05 , ada hubungan antara variabel pretest \& variabel posttest.

Selanjutnya. hasil pengujian paired samples test diketahui sig. (2-tailed) adalah sebesar $0,000<0,05$. Hal ini berarti, $\mathrm{H}_{0}$ ditolak dan $\mathrm{H}_{\mathrm{a}}$ diterima. Dapat disimpulkan bahwa ada perbedaan rata-rata atau mean antara penguasaan konsep insight photo therapy pretest dengan posttest yang artinya ada pengaruh pelatihan insight photo therapy untuk meningkatkan keterampilan konseling Guru BK.

\section{Penguasaaan prosedur insight photo therapy}

Pada output ini diperlihatkan ringkasan hasil statistik deskriptif dari kedua sampel yang diteliti yaitu nilai pretest dan posttest. Nilai pretest diperoleh rata-rata penguasaan prosedur insight photo therapy sebesar 4,49. Sedangkan untuk nilai posttest diperoleh nilai rata-rata penguasaan prosedur insight photo therapy sebesar 7,79. Jumlah responden atau subjek penelitian adalah sebanyak 100 orang. Nilai standar std. Deviation (standar deviasi) 
pada pretest sebesar 2,250 dan posttest 0,977. Terakhir adalah nilai std. Error mean untuk pretest sebesar 0,225 dan untuk posttest sebesar 0,098.

Karena nilai rata-rata penguasaan konsep insight photo therapy pada pretest 4,49 $<$ posttest 7,79, maka artinya secara deskriptif ada perbedaan rata-rata penguasaan prosedur insight photo therapy antara pretest \& posttest. Selanjutnya, untuk membuktikan apakah perbedaan signifikan, perlu ditafsirkan uji paired sample $t$ test. Diketahui nilai koefisien korelasi sebesar 0,185 dengan nilai signifikansi (sig.) sebesar 0,065. Nilai sig. 0,065 > probabilitas 0,05 , berarti tidak ada hubungan antara variabel pretest \& variabel posttest.

Berdasarkan pengujian paired samples test, diketahui sig. (2-tailed) adalah sebesar $0,000<0,05$. Artinya, $\mathrm{H}_{0}$ ditolak dan $\mathrm{H}_{\mathrm{a}}$ diterima. Dapat disimpulkan bahwa ada perbedaan rata-rata antara penguasaan prosedur insight photo therapy pretest dengan posttest yang artinya ada pengaruh pelatihan insight photo therapy untuk meningkatkan keterampilan konseling Guru BK.

\section{Penguasaaan keterampilan praktik mandiri insight photo therapy}

Pada output ini diperlihatkan ringkasan hasil statistik deskriptif dari kedua sampel yang diteliti yaitu nilai pretest dan posttest. Nilai pretest diperoleh rata-rata penguasaan keterampilan praktik mandiri insight photo therapy sebesar 6,93. Sedangkan untuk nilai posttest diperoleh nilai rata-rata penguasaan keterampilan praktik mandiri insight photo therapy sebesar 7,72. Jumlah responden atau subjek penelitian adalah sebanyak 100 orang. Nilai standar std. Deviation (standar deviasi) pada pretest sebesar 1,380 dan posttest 0,866 . Terakhir adalah nilai std. Error mean untuk pretest sebesar 0,138 dan untuk posttest sebesar 0,087 .

Karena nilai rata-rata penguasaan konsep insight photo therapy pada pretest 6,93 $<$ posttest 7,72, maka artinya secara deskriptif ada perbedaan rata-rata penguasaan keterampilan praktik mandiri insight photo therapy antara pretest \& posttest. Untuk membuktikan apakah perbedaan signifikan, perlu ditafsirkan pada hasil uji paired sample $t$ test. Nilai koefisien korelasi sebesar 0,212 dengan nilai signifikansi (sig.) sebesar 0,034. Nilai sig. 0,034 < probabilitas 0,05 . Jadi, hubungan antara variabel pretest \& posttest.

Berdasarkan pengujian paired samples test, diketahui sig. (2-tailed) adalah sebesar $0,000<0,05$. Artinya, $\mathrm{H}_{0}$ ditolak dan $\mathrm{H}_{\mathrm{a}}$ diterima. Dapat disimpulkan bahwa ada perbedaan rata-rata atau mean antara penguasaan keterampilan praktik mandiri insight photo therapy pretest dengan posttest yang artinya ada pengaruh pelatihan insight photo therapy untuk meningkatkan keterampilan konseling Guru BK.

4. Keberhasilan membantu menyelesaikan masalah siswa melalui insight photo therapy

Pada output ini diperlihatkan ringkasan hasil statistik deskriptif dari kedua sampel yang diteliti yaitu nilai pretest dan posttest. Nilai pretest diperoleh rata-rata keberhasilan membantu menyelesaikan masalah siswa melalui insight photo therapy sebesar 7,05. Sedangkan untuk nilai posttest diperoleh nilai rata-rata keberhasilan membantu menyelesaikan masalah siswa melalui insight photo therapy sebesar 7,70. Jumlah responden atau subjek penelitian adalah sebanyak 100 orang. Nilai standar std. Deviation (standar deviasi) pada pretest sebesar 1,459 dan posttest 0,980. Terakhir adalah nilai std. Error mean untuk pretest sebesar 0,146 dan untuk posttest sebesar 0,098.

Karena nilai rata-rata penguasaan konsep insight photo therapy pada pretest 7,05 $<$ posttest 7,70, artinya secara deskriptif ada perbedaan rata-rata keberhasilan membantu menyelesaikan masalah siswa melalui insight photo therapy antara pretest \& posttest. Untuk membuktikan apakah perbedaan signifikan, perlu ditafsirkan pada hasil uji paired sample $t$ test. Nilai koefisien korelasi sebesar 0,357 dengan nilai sig. sebesar 0,000. Karena nilai sig. $0,000<$ probabilitas 0,05 , berarti ada hubungan antara variabel pretest dan variabel posttest.

Berdasarkan pengujian paired samples test, diketahui sig. (2-tailed) adalah 0,000< 0,05 , berarti $\mathrm{H}_{0}$ ditolak \& $\mathrm{H}_{\mathrm{a}}$ diterima. Kesimpulannya, ada perbedaan rata-rata atau mean antara keberhasilan membantu menyelesaikan masalah siswa melalui insight photo 
therapy pretest dengan posttest yang artinya ada pengaruh pelatihan insight photo therapy untuk meningkatkan keterampilan konseling Guru BK.

Hasil pengujian paired samples test dari masing-masing aspek keterampilan konseling melalui insight photo therapy diketahui sig. (2-tailed) adalah sebesar $0,000<$ 0,05 . Artinya, $\mathrm{H}_{0}$ ditolak \& $\mathrm{H}_{\mathrm{a}}$ diterima. Dapat disimpulkan bahwa ada perbedaan rata-rata atau mean antara pretest dengan posttest keterampilan konseling melalui insight photo therapy yang artinya ada pengaruh pelatihan insight photo therapy untuk meningkatkan keterampilan konseling Guru BK. Secara eksplisit, pelatihan insight photo therapy efektif secara signifikan dalam meningkatkan keterampilan konseling Guru BK. Temuan ini sangat penting karena guru BK dapat upgraiding wawasan, sikap dan keterampilan konselingnya di masa pandemi, khususnya menggunakan insight photo therapy yang terbukti efektif dalam meningkatkan skill konseling guru BK.

Keberhasilan peningkatan keterampilan konseling ini tidak lepas dari keunikan insight photo therapy itu sendiri. Pendekatan konseling yang belum begitu familier, membuat Guru BK merasakan sensasi dan antusias yang baik. Saat pelaksanaan simulasi dan latihan praktik terbimbing, peneliti melakukan simulasi latihan konseling individual dan kelompok menggunakan moda daring berbasis website di https://www.points-of-you.com/play/welcome. Pada website tersebut telah dikemas visualisasi yang mengarahkan pada prosedur kegiatan konseling mulai dari framing, choosing, expanding, focusing dan doing. Sebelum konseli memasuki framing, dimulai dengan kegiatan relaksasi melalui alunan musik yang mengantarkan konseli dalam keadaan yang lain nyaman dan rileks.

Selanjutnya, tahapan atau prosedur Insight photo therapy dilakukan secara sistematis dan operasional, yaitu:

1. FRAMING. Memilih masalah dari kehidupan sehari-hari konseli, masalah yang paling dikhawatirkan, mungkin juga sesuatu yang ingin dilihat secara mendalam (hubungan pribadi, karier, keluarga, teman, dan seterusnya), dan membingkai masalah konseli sebagai pertanyaan. Contoh percakapan: "Mengapa orang lain tidak suka berteman denganku?"

2. CHOOSING. Mengajak konseli untuk memilih kartu secara intuitif, menghadap ke atas atau ke bawah. Contoh percakapan: "Saudara diberikan kesempatan memilih 3 foto/gambar, akan memilih dalam posisi terbuka atau tertutup?"

3. EXPANDING. Mendorong konseli untuk mengamati setiap kartu dengan cermat, perhatikan pikiran dan perasaan yang datang. Contoh percakapan: "Apa yang saudara lihat dari gambar tersebut? Sudut pandang apa yang saudara dapatkan? Apa yang disukai atau tidak disukai dari dambar tersebut?"

4. FOCUSING. Menanyakan pada konseli, "Sudut pandang apa yang paling signifikan atau bermakna dari pengamatan ini jika dikaitkan dengan permasalahan yang sedang dirasakan?". Konselor mengarahkan sudut pandang dari gambar yang diamati dengan mengkorelasikan permasalahan yang sedang dikhawatirkan konseli.

5. DOING. Pertanyaan panduan konselor pada konseli adalah "Bagaimana Saudara bisa menerapkan sudut pandang tersebut ke dalam kehidupan nyata nanti"? artinya bahwa mengarahkan konseli mampu merumuskan langkah-langkah konkrit yang segera dilakukan setelah sesi konseling ini (Yudha, 2019).

Karena insight photo therapy adalah bentuk komunikasi emosional, bukan sebagai seni, tidak ada pengalaman sebelumnya dengan kamera atau seni fotografi yang diperlukan (Weiser, 2018), dan akhirnya, karena semua tahapan ini melibatkan konselor-konseli yang berinteraksi dengan konstruksi visual mereka sendiri secara unik dan nyata, konseling ini sangat membantu bagi orang-orang yang mengalami kesulitan komunikasi verbal karena alasan fisik, mental, atau emosional. Selain itu, mereka yang berada dalam situasi pengecualian sosial, prosedur ini sangat menstimulasi untuk menemukan banyak wawasan dari masalah yang sedang dikhawatirkan saat ini sekaligus mendapatkan keberhasilan dari sesi konseling.

Weiser (2018) menambahkan bahwa setiap foto yang diambil atau disimpan seseorang merupakan jenis potret diri, sejenis cermin dengan ingatan yang merefleksikan kembali saat-saat itu dan orang-orang yang cukup spesial untuk dibekukan dalam waktu yang lama. Secara kolektif, foto-foto tersebut membuat kisah nyata dari kehidupan orang itu sendiri, berfungsi sebagai jejak 
kaki visual yang menandai di mana mereka berada (secara emosional, juga secara fisik) dan mungkin juga memberi sinyal ke mana mereka akan pergi. Bahkan reaksi orang terhadap kartu pos, gambar majalah, gambar online, atau gambar yang diambil oleh orang lain dapat memberikan petunjuk yang menerangi kehidupan batin mereka sendiri dan rahasianya.

Arti sebenarnya dari setiap foto tidak terletak pada fakta visualnya, lebih pada detail-detail pada foto/gambar yang mampu membangkitkan pikiran (dan hati) setiap konseli (Weiser \& Walker, 2020). Saat melihat sebuah foto, orang sebenarnya secara spontan menciptakan makna yang menurut mereka berasal dari foto itu sendiri, dan mungkin bukan makna yang ingin disampaikan oleh fotografer/pengambil gambar. Dengan demikian, maknanya (dan pesan emosional) tergantung pada siapa yang melakukan pengamatan, karena persepsi orang dan pengalaman hidup yang unik secara otomatis membingkai dan mendefinisikan apa yang dilihat sebagai nyata. Oleh karena itu, reaksi orang-orang terhadap foto yang mereka rasa spesial dapat benar-benar mengungkapkan banyak hal tentang diri mereka sendiri, dari pertanyaan-pertanyaan yang diajukan oleh konselor.

Di bawah arahan seorang konselor yang terlatih dalam Insight Photo Therapy, konseli mengeksplorasi foto-foto dengan wawasan, emosi dan mengutarakan informasi-informasi dari visualisasi foto/gambar tersebut. Informasi seperti itu laten di semua foto, dapat digunakan untuk memfokuskan dan mempercepat dialog terapeutik, hubungan yang lebih langsung dengan alam bawah sadar konseli dapat dimunculkan. (Kim \& Cho, 2017) menekankan bahwa selama sesi PhotoTherapy, konseli tidak hanya secara pasif tercermin dalam perenungan diam, tetapi keterampilan konselor mendirektif mereka secara aktif selama sesi (atau setelah), mampu melakukan dialog konstruktif, mendengarkan insight atau wawasan dari konselor maupun konseli lainnya (jika dalam konseling kelompok), merekonstruksi, membentuk atau menggambarkan narasi baru, yang didapatkan dan dikumpulkan selama sesi, kemudian divisualisasikan kembali dalam memori atau imajinasi, diintegrasikan ke dalam ekspresi kreatif yang kesemuanya ini bertujuan mengarahkan konseli mampu menemukan langkah konkrit yang harus dilakukan setelah mengikuti sesi photo therapy.

Menurut Waiser \& Wheeler (Tan, 2020) Insight PhotoTherapy harus dimaknai suatu sistem yang saling terkait sebagai pendekatan konseling berbasis foto oleh para profesional kesehatan mental, konselor maupun guru BK terlatih. Pendekatan ini bisa menjadi salah satu alternatif sebagai bagian dari praktik terapeutik dalam membantu konseli secara sadar untuk mampu menyelidiki, dan kemudian secara kognitif mengintegrasikan kembali wawasan yang diendapkan dalam foto atau gambar sehingga lebih memahami diri dan mengarahkan kehidupan mereka dengan lebih baik.

Temuan-temuan penelitian ini menambahkan temuan empiris sebelumnya. Pada penelitian empiris sebelumnya terkait peningkatan skill konseling bagi guru BK, diidentifikasi oleh Kusmaryani (Lianawati, 2018) bahwa keterampilan konseling belum dikuasai seutuhnya oleh guru BK/Konselor. Menurutnya, keterampilan konseling guru BK masih sangat minim. Bahkan, beberapa guru tidak menggunakannya sama sekali. Selain itu, beberapa keterampilan ditafsirkan berbeda-beda, sehingga dalam praktiknya tidak sesuai.

Temuan penelitian sebelumnya juga menyebutkan bahwa penggunaan photo therapy terbukti sebagai praktik terbaik dalam pekerjaan sosial klinis (DeCoster \& Dickerson, 2014). Photo therapy bisa diterapkan pada orang dewasa (Jones, 2016). Insight photo therapy efektif dalam membantu bagi orang-orang yang mengalami kesulitan komunikasi verbal karena alasan fisik, mental, atau emosional, serta mereka yang berada dalam situasi pengecualian sosial (Weiser, 2018; N. Gibson, 2017).

Photo therapy mampu membantu proses konseling bagi orang yang membutuhkan kesembuhan (Ginicola et al., 2012a; Ginicola et al., 2012b). Photo therapy membantu konseli dengan perilaku self-injuring (Briggs, 2013). Photo therapy dapat menumbuhkan empati, kesadaran diri, dan self-disclosure (Wilkes, 2012). Photo therapy juga membantu permasalahan depresi (Dirmaier et al., 2012). Dalam perbedaan latar di Indonesia, hasil penelitian menunjukkan insight photo therapy juga dapat diterapkan di Indonesia, terutama untuk meningkatkan kemampuan konseling guru BK, yang di dalamnya memuat keterampilan komunikasi verbal \& non verbal oleh para konselor itu sendiri. 
Karena photo therapy adalah kumpulan strategi dan prosedur yang fleksibel, tidak hanya pada satu modalitas teoretis atau paradigma terapeutik tertentu, pendekatan ini dapat digunakan segala jenis konselor atau terapis terlatih, terlepas dari pendekatan konseptual yang mereka sukai. Ini adalah salah satu dari banyak pendekatan konseling kreatif yang dapat digunakan dengan begitu sukses oleh berbagai profesional kesehatan mental, konselor maupun Guru BK yang tidak terlatih secara khusus. Para profesional boleh mengembangkan foto-foto sesuai dengan kebutuhan dan insight masing-masing (Weiser, 2018).

Namun, terdapat tantangan dan mungkin bisa menjadi hambatan pelaksanaan insight photo therapy, khususnya bagi pemula, di antaranya: (1) keterampilan direktif seorang konselor dalam mengeksplorasi masalah klien; (2) keterampilan interpretasi pemaknaan foto atau gambar dari kilen pasti beragam; (3) memfokuskan pikiran agar masalah klien tidak bias saat banyak insight yang muncul; (4) variasi foto atau gambar bernuansa teraputik yang senantiasa diupgrage; (5) keluasan wawasan, ketangkasan berpikir dan keterampilan refleksi dari konselor. Hal ini perlu disikapi dengan pengenalan secara mendalam, pelatihan yang konstruktif dan akhirnya akan menjadi sebuah pembiasaan penerapan insight photo therapy yang menarik.

Selain dibutuhkan keterampilan direktif seorang konselor, hasil penelitian ini juga memiliki keterbatasan yaitu, penelitian berlaku bagi sampel penelitian. Apabila diterapkan dalam populasi lain, bisa jadi memiliki hasil yang berbeda. Keterbatasan hasil penelitian ini juga ada pada rentang waktu. Mereka yang telah mengikuti pelatihan insight photo therapy, bisa saja kemampuannya berubah seiring berkembangnya waktu dan proses belajar mereka. Mereka bisa saja mengalami proses belajar, sehingga hasil penelitian bisa semakin meningkat. Bisa juga sebaliknya, karena seiring berkembangnya waktu, para guru BK atau mahasiswa yang telah mengikuti pelatihan ini tidak meng-upgrade ilmu konseling lagi, kemampuan konselingnya justru menjadi menurun. Oleh karena itu, hasil penelitian ini memiliki keterbatasan baik dari segi keterampilan direktif konselor, ruang lingkup, dan waktu.

Sebagai penutup, peneliti menyampaikan kekuatan foto yang ditulis oleh Judy Weiser. Tulisan Judy Weiser tentang the power of photo, yaitu "Foto-foto adalah jejak kaki pikiran kita, cermin kehidupan kita, refleksi dari hati kita, kenangan beku yang bisa kita tahan dalam keheningan yang diam di tangan kita, selamanya jika kita mau. Mereka mendokumentasikan tidak hanya di mana kita berada, tetapi juga menunjukkan jalan ke mana kita akan tuju, tanpa kita menyadarinya atau tidak." (Weiser, 2018).

Pada penelitian selanjutnya, diharapkan hasilnya juga dapat menyumbangkan literasi teoritis dan praktis bagi khasanah ilmu pengetahuan bidang Bimbingan Konseling serta melakukan verifikasi pengaruh insight photo therapy dalam meningkatkan keterampilan konseling Guru BK. Diharapkan hal tersebut dilakukan dengan menindaklanjuti penelitian dan pengembangan selanjutnya, meliputi metode, prosedur pelaksanaan, sasaran, dan sebagainya.

\section{Simpulan}

Hasil penelitian menunjukkan bahwa pelatihan insight photo therapy efektif secara signifikan untuk meningkatkan keterampilan konseling Guru BK. Keterampilan konseling guru BK sangat penting untuk ditingkatkan mengingat pandemi COVID-19 berdampak pada kesehatan mental siswa yang sangat serius. Dari hasil penelitian diharapkan mampu memberikan sumbangsih bagi bidang ilmu Bimbingan Konseling dan manfaat praktis terutama bagi para Guru BK. Melalui insight photo therapy, ada pesan secara implisit maupun eksplisit bagi konselor/Guru BK untuk memperhatikan sesi konseling agar tidak membosankan, kurang bermakna dan tidak memberikan solusi bagi permasalahan peserta didik di saat pembelajaran jarak jauh. Konseling dengan media foto atau gambar membawa suasana segar, menarik dan menyenangkan melalui nuansa diskusi antara konselor dengan konseli dalam menemukan sudut pandang dari suatu gambar tertentu dan dikorelasikan dengan permasalahan yang sedang dikhawatirkan konseli melalui dialog konstruktif serta penciptaan makna disetiap prosedurnya. 


\section{Ucapan Terima Kasih}

Ucapan terimakasih kepada Lembaga Penelitian dan Pengabdian Masyarakat (LPPM) Universitas Sebelas Maret (UNS) atas kesempatan dan dukungan kepada peneliti untuk dapat melaksanakan penelitian ini sampai tuntas dan selesai.

\section{Daftar Rujukan}

Al-Sulaiman, R. J., Bener, A., Doodson, L., Al Bader, S. B., Ghuloum, S., Lemaux, A., Bugrein, H., Alassam, R., \& Karim, A. (2018). Exploring the effectiveness of crisis counseling and psychoeducation in relation to improving mental well-being, quality of life and treatment compliance of breast cancer patients in Qatar. International Journal of Women's Health, 10, 285.

Alsafi, Z., Abbas, A.-R., Hassan, A., \& Ali, M. A. (2020). The coronavirus pandemic: adaptations in medical education. International Journal of Surgery (London, England).

Briggs, M. M. (2013). Picturing self empowerment: a phenomenological study of adolescent girls that self injure involved in phototherapy group work. Kansas State University.

Brooking.Edu. (2020). Corona Virus (COVID-19).

Cao, W., Fang, Z., Hou, G., Han, M., Xu, X., Dong, J., \& Zheng, J. (2020). The psychological impact of the COVID-19 epidemic on college students in China. Psychiatry Research, 287, 112934.

Chen, W.-C., Huang, A. S., Chuang, J.-H., Chiu, C.-C., \& Kuo, H.-S. (2011). Social and economic impact of school closure resulting from pandemic influenza $\mathrm{A} / \mathrm{H} 1 \mathrm{~N} 1$. Journal of Infection, 62(3), 200-203.

Creswell, J. W., \& Creswell, J. D. (2017). Research design: Qualitative, quantitative, and mixed methods approaches. Sage publications.

DeCoster, V. A., \& Dickerson, J. (2014). The therapeutic use of photography in clinical social work: Evidence-based best practices. Social Work in Mental Health, 12(1), 1-19.

DHSC. (2020). Department of Health and Social Care.

Dirmaier, J., Steinmann, M., Krattenmacher, T., Watzke, B., Barghaan, D., Koch, U., \& Schulz, H. (2012). Non-pharmacological treatment of depressive disorders: a review of evidence-based treatment options. Reviews on Recent Clinical Trials, 7(2), 141-149.

Faqir, A. . (2020). Kemendikbud Catat 646.200 Sekolah Tutup Akibat Virus Corona.

Fauziah, M., \& Hartanto, D. (2020). PROFIL PENGALAMAN SITUASI KRISIS PADA MAHASISWA. PD ABKIN JATIM Open Journal System, 1(2), 84-90.

Gibson, N. (2017). Therapeutic photography: Enhancing patient communication. Journal of Kidney Care, 2(1), 46-47.

Gibson, R. L. \& M. H. M. (2011). Bimbingan dan Konseling. Pustaka Pelajar.

Ginicola, M. M., Smith, C., \& Trzaska, J. (2012a). Counseling through images: Using photography to guide the counseling process and achieve treatment goals. Journal of Creativity in Mental Health, 7(4), 310-329.

Ginicola, M. M., Smith, C., \& Trzaska, J. (2012b). Using Photography in Counseling: Images of Healing. International Journal of the Image, 2(2).

Jones, D. (2016). The Effectiveness of Phototherapy in working with Adolescents. UC Merced Undergraduate Research Journal, 8(2).

Keogh-Brown, M. R., Jensen, H. T., Edmunds, W. J., \& Smith, R. D. (2020). The impact of Covid19, associated behaviours and policies on the UK economy: A computable general equilibrium model. SSM-Population Health, 12, 100651.

Kim, S., \& Cho, G. (2017). Effect of a Group Counseling Program With Phototherapy on Enhancing the Self-Perception and Self-Esteem of Female Middle School Students. Korean Journal of Child Studies, 38(2), 177-190.

Lianawati, A. (2018). Implementasi keterampilan konseling dalam layanan konseling individual. Seminar Nasional Bimbingan Dan Konseling Jambore Konseling 3.

Meier, K., Glatz, T., Guijt, M. C., Piccininni, M., Van Der Meulen, M., Atmar, K., Jolink, A.-T. C., Kurth, T., Rohmann, J. L., \& Zamanipoor Najafabadi, A. H. (2020). Public perspectives on 
protective measures during the COVID-19 pandemic in the Netherlands, Germany and Italy: A survey study. PloS One, 15(8), e0236917.

Nayak, D. N., Kumar, R., \& Savalia, C. V. (2020). The Socio-economic Impacts of the COVID-19 Pandemic: A Review. Int. J. Curr. Microbiol. App. Sci, 9(11), 562-566.

Nicola, M., Alsafi, Z., Sohrabi, C., Kerwan, A., Al-Jabir, A., losifidis, C., Agha, M., \& Agha, R. (2020). The socio-economic implications of the coronavirus and COVID-19 pandemic: a review. International Journal of Surgery.

Prabhakar, R. (2020). Universal basic income and Covid-19. IPPR Progressive Review, 27(1), 105.

Putra, P., Liriwati, F. Y., Tahrim, T., Syafrudin, S., \& Aslan, A. (2020). The students learning from home experiences during Covid-19 school closures policy in Indonesia. Jurnal Iqra': Kajian IImu Pendidikan, 5(2), 30-42.

Rahayu, S. M. (2017). Konseling Krisis: Sebuah Pendekatan Dalam Mereduksi Masalah Traumatik Pada Anak Dan Remaja. JP (Jurnal Pendidikan): Teori Dan Praktik, 2(1), 65-69.

Romli, M. E. (2017). Upaya konselor untuk mengatasi trauma di kalangan mahasiswa. PROCEEDING IAIN Batusangkar, 1(1), 171-175.

Santoso. (2014). Panduan Lengkap SPSS Versi 20. PT Elex Media Komputindo.

Singh, V., \& Thurman, A. (2019). How many ways can we define online learning? A systematic literature review of definitions of online learning (1988-2018). American Journal of Distance Education, 33(4), 289-306.

Sugiyono. (2018). Metode Penelitian Kuantitatif, Kualitatif, dan R\&D. Alfabeta.

Surur, N., Makhmudah, U., \& Hartanto, A. P. (2020). PENGEMBANGAN KURIKULUM BIMBINGAN DAN KONSELING KOMPREHENSIF SMK DI ERA REVOLUSI INDUSTRI 4.0. JURNAL BIMBINGAN DAN KONSELING AR-RAHMAN, 6(2), 120-125.

Susanto, A. (2018). Bimbingan dan Konseling di Sekolah: Konsep, Teori, dan Aplikasinya. Kencana.

Tan, E. M. M. (2020). An Overview: Visual Communication in Photography as Healing Therapy. วารสาร ศิลป์ พี ระ ศรี, 8(1-2), 302-316.

Tourigny, L., \& Naydenova, I. (2020). Using Therapeutic Photography Techniques to Increase the Wellbeing of College Students. Journal of Counseling and Psychology, 3(1), 4.

Usman, T. (2020). Sistem PJJ Solusi Terbaik Pendidikan di Masa Pandemi. Republika.

Weiser, J. (2018). Phototherapy techniques: Exploring the secrets of personal snapshots and family albums. Routledge.

WHO. (2020). Coronavirus disease (COVID-19) pandemic.

Widowati, D. (2019). Peran Corporate Communication PT Krakatau Steel dalam Mengatasi Krisis. Communicare: Journal of Communication Studies, 6(2), 190-203.

Wilkes, D. (2012). The Use Of A Phototherapy Intervention To Foster Empathy, Self-awareness, And Self-disclosure In Counselors-in-training Using The Personal Growth Group.

Yudha, E. S. (2019). Insight Photo Therapy. Hangout. In konvensi ABKIN.

\section{Competing interests:}

The authors declare that they have no significant competing financial, professional or personal interests that might have influenced the performance or presentation of the work described in this manuscript. 